\title{
Актуальные проблемы филологии
}

\author{
Инна Калита (Ústí nad Labem)
}

Актуальные проблемы филологии. Материалы международной научной конференции, г. Донецк, 14-15 мая 2015. Литературоведческий сборник. Вып. 53-54. Отв. ред. А. А. Кораблев. Донецк: ДонНУ, 2015. 232 с. ISBN 966-72-77-79-8.

Рецензируемый литературоведческий сборник - материалы конференции, прошедшей в Донецком национальном университете в 2015 г. Сборник состоит из трех разделов: 1. Онтология и поэтика, 2. Поэтика и аналитика. Каждый раздел содержит 11 статей. Завершает сборник содержательный раздел - Дискуссии.

Раздел Онтология и поэтика открывает статья В. В. Федорова «О предмете филологии» (с. 5-12), структурирующая понятия филология, лингвистика и литературоведение. В. М. Калинкин в статье «Поэтонимология и литературоведение» (с. 13-19) ставит цель уточнения отношений между поэтонимологией и литературоведением. Поэтонимология использует комплексный подход, объединяющий опыт и методы литературоведения и языкознания, и занимается исследованием поэтики собственных имен, функционирующих в литературно-художественных текстах. Статья четко вписывается в общую канву конференции и разрабатывает вопрос о взаимооотношениях лингвистики и литературоведения, который далее обсуждается и в дискуссии.

О. Р. Миннуллин. «Где тогда встреча лингвистики и литературоведения на территории поэтонимологии?»

В. М. Калинкин. «Мир имен разделен на две части: в одной имена, которые обозначают реальные вещи, они называются онимами; в другой имена, которые обслуживают художественные миры, они называются поэтонимами. Между ними непроходимой гранииы нет, потому что поэтонимы появляются из онимии, но при этом они не становятся именами реальных объектов» (с. 184).
Статья А. А. Кораблева «Филология земли: приниипы и перспективы геопоэтики» (с. 20-30) посвящена объяснению относительно молодого термина «геопоэтика», возникшего в конце XX века. Ученый подробно представляет не только путь данного термина, но также знакомит и с «отцом» геопоэтики, уроженцем Шотландии - Кеннетом Уайтом (1936 г. р). «Соединение пространственной предопределенности и творческой свободы выразилось в понятии «геопоэтика", которое Кеннет Уайт формировал и внедрял последовательно и конструктивно»: с 1978 г. К. Уайт начал использовать термин в своих лекциях и публикациях, в 1987 г. сформулировал «Элементы геопоэтикu»; в 1989 г. создал в Париже Международный институт геопоэтики; в 1994 г. изложил свой метод в книге «Альбатросова скала: Введение в геопоэтику» (с. 20).

«Геопоэтика знаменует новый этап в ритмике поэтологических предпочтений. Если академическое литературоведение XIX века тлготело $\kappa$ аристотелевской поэтике, с ее миметической обусловленностью, а в XX веке доминируют представления о трансиендентных истоках творчества, то в XXI веке геопоэтика стала знаком возврашения к природной предопределенности, однако осмысленной как предустановленное проявление трансиендентности.

Геопоэтика явилась как теоретическал антитеза исторической поэтики (вспомним тезис К. Уайта: «География всегда больше истории»), однако не отменила ее, а предстала как ее креативный коррелят, более основательный, чем наииопоэтики, хотя бы потому, ито кониепт «земля» все же более фундаментален и первичен, чем кониепты «народ» или «начия» (с. 26). А. Кораблев представляет 
геопоэтику как закономерную поэтологическую тенденцию конца XX - начала XXI вв. и коррелят «исторической поэтики».

О. Н. Купцова в статье «К проблеме мета mеатра» (с. 31-38) рассматривает метатеатр как частный случай широкого вопроса «зеркальности» и «двойничества» в театральном зрелище, или как «самоотражение театра, созданное с помощью удвоения (или мультипли каиии) его элементов». Исследовательница обращается к различным этапам развития русской и мировой театральной традиции, рассказывает о спорах начала XX века. Приводя конкретные примеры, автор констатирует, что XX-й век не открывает, а лишь актуализирует и интерпретирует метатеатральность.

B. В. Стамати рассматривает понятие поэтического письма. Используя компаративный подход он подвергает детальному пересмотру ранее высказанное по данному вопросу. В своей статье Стамати приходит к следующему выводу: «литературная тра дичия, предполагаюомая наличие актуальной совокупности маркеров, определяюших ее облик, является парадигмой осознаний знаков поэтического писъма как некой архиформы, на которую ориентируется писатель, чтобы его письмо стало литературой» (с. 39-44).

Эстетическая концепция и постулаты М. Бахтина лежат в основе статей К. В. Першиной и С. А. Белоконь. К. В. Першина в своей статье «Авторская вненаходимость в этическом аспекте» высказывает предложение, что «позииия вненаходимости - это непосредственное, буквальное, добровольное исключение поэтом себя в эстетической деятельности из связей и за конов фактической действительности, единого для всех и единственного для поэта бытия, исключение из его благой данности. Эстетической оббект - это форма видения наличного бытия, обеспеченная и освященная невозможной и осуще ствившейся вненаходимостью поэта, в которой он как человек является существуюшим и несуществуюшим одновременно» (с. 45-51).

С. А. Белоконь рассматривает специфику отношений в триаде «автор - герой - читатель» в индивидуально-авторскую эпоху (с. 52-57). Попыткой рассмотрения вопроса о научной обоснованности термина «религиозная филология» является статья А. Н. Городеского «Кониепиия Р. Бультмана в русле религиозной филологии» (с. 58-64).

Содержательная статья «Чудесная реальность» и структура пространства в контексте магического реализма» М. Н. Панчехиной опирается на идею «чудесной реальности», предложенную А. Карпентьером. Исследовательница подробно анализирует идеи Карпентьера и наглядно указывает значительность этой фигуры в развитии базисных основ рассматриваемого метода. Как и некоторые другие исследователи, М. Н. Панчехина опровергает представление о том, что магический реализм - явление, принадлежащее исключительно латиноамериканской литературе XX века, и считает магический реализм вполне утвердившимся методом, «историческое и теоретическое осмысление которого не сводится кединственной культуре и не замыкает ся на конкретной начиональной традииии. <...> Кониепиия «иудесной реальности», предложенная Карпентвером и в дальнейшем трансформирован ная Маркесом, действительно оказывается способом построения особой художественной протяжённости, у которой выражена своя собственная структура. Она разомкнута и обращена едва ли не ко всему миру, постигаемому автором в прочессе творчества. Что касается исторического развития и трансформаиии «иудесной реальности", то в дальнейшем она становится основой для карнавализованной картины мира» (с. 65-71). М. Н. Панчехина рассматривает магический реализм как метакатегорию, и в отличие от других современных исследователей магического реализма, не выделяет критерии чудесности, считая, что они могут разрушить чудо.

Одним из ведущих вопросов статьи Е. С. Рубинской «Методологические проблемъ изучения музыкальности литературных произведений» (с. 72-78) является вопрос унификации терминологического аппарата взаимодействующих искусств для адекватного описания интермедиальных процессов. Обозначенная проблема касается музыковедческих 
терминов, не функционирующих в литературоведении и попадающих в поле зрения филологов в рамках интермедиальных исследований, в которых эти термины чаще используются в метафорическом, ненаучном значении. Задачу литературоведа в таких исследованиях Рубинская видит в истолковании вольного толкования и объяснении термина с точки зрения филологии, культурологии или другой области знания, породившей обозначенную ошибку.

Т. В. Коренькова отмечает, что методика преподавания русской литературы и культуры как иностранной (РЛиККИ) находится в стадии осмысления как новое междисциплинарное направление. В ее статье «Литературоведческая герменевтика в курсе методики РЛиККИ (к вопросу учёта традичий иноначиональных речепиий русской литературы)» приведено множество интересных примеров, а также рейтинг читательских пристрастий в разных странах. Из них явственно следуют различия, «каждая начиональнал культура «резонирует» (реагирует, замечает, отбирает, усваивает) именно те факты инокультуры-собеседни$\kappa a$, которые отвечают логике ее собственного развития» (с. 79-89). «Проблемным» в данной статье кажется используемый термин - аббревиатура РЛиККИ. Речь идет о методике преподавания русской литературы и культуры как иностранной. В состав аббревиатуры входят два предлога - $u$ и $к$. Один из них пишется в РЛиККИ с маленькой буквы, второй - с большой. Думается, что и грамматическая коррекция на РЛиКкИ не будет содействовать его широкой адаптации в научных кругах. Вместо названной аббревиатуры возможно беспредложное образование - РЛКИ, фонологически ассоциирующееся с хорошо известным термином РКИ (русский как иностранный). Изучение языка и литературы как иностранных в наше время всегда включает знакомство с «культурным компонентом», т.н. фоновыми знаниями. Т.е. речь идет об известном подходе при изучении языка, сформулированном и обоснованном в лингвострановедческой теории Е. М. Ве- рещагина и В. Г. Костомарова в начале 80-х г. XX в.; далее дополненной и расширенной в работах русских лингвокультурологических школ и словацкой Прешовской лингвокультурологической школы, и неустанно развиваемом в настоящее время. Безусловно, изучение литературы как иностранной в сравнении с изучением языка как иностранного имеет свою специфику и требует включения дополнительных информативных составляющих. Однако терминология родственных областей может быть построена в подобном стиле. Использованный в статье термин кажется не совсем удачным.

\section{Раздел Поэтика и аналитика}

Разным аспектам и взаимосвязям творчества А. С. Пушкина во втором разделе посвящены несколько статей: «Диалог с Пушкиным в стихотворении Владимира Соколова «Яустал от двадцатого века...» О. Р. Миннуллина (с. 160-168); статья Л. П. Квашиной, посвященная «взаимоотношениям» черновика и окончательного текста романа «Евгений Онегин» (с. 90-99); И. А. Балашова рассматривает творчество А. Орловского - мастера профильного портрета через призму восприятия А. Пушкина (с. 100-106). В пушкинскую эпоху окунает читателя статья И. С. Юхновой «Гусарский миф Дениса Давыдова» (с. 107-110).

И. А. Попова-Бондаренко рассматривает трансформацию библейского кода в поэме Г. Гейне «Германия. Зимняя сказка» (с. 111-120). Специфике гоголевского историзма посвящена статья О. А. Кравченко (с. 121-127). Вопросом поэтической ономастики занимается в своей статье «Имя в списке действуюших лич и в тексте пвесы ( Воспитаннича» А. Н. Островского)» И. Н. Исакова (с. 128-138). Доклад Н. В. Пращерук сосредотачивает внимание на интертекстуальной составляющей повести Н. С. Лескова «Леди Макбет Миенского уезда» (с. 139-137). Л. Н. Житкова анализирует приемы мифологизации в литературно-критических работах Д. С. Мережковского (с. 148-152). Переводческим аспектом интерпретации поэтического 
текста занимается К. С. Федотова (с. 153-159). Теоретические аспекты понятия «топос» на материале лирики Л. Аронзона проанализированы Т. П. Хайрулиным (с. 169-175).

Печальную игру слов, которую находим в «стенограмме» - «стенодрамме» А. А. Кораблева, можно было бы сделать эпиграфом, т.к. приводимое сравнение отражает современнное «неравновесное» состояние человеческого существования, в котором вопрос мира в отдельных регионах становится ежедневной, но нерешаемой «проблемой».

«TERRA PHILOLOGIA: стенодрама научной конферениии «Актуальнъе проблемы филологии». Донечкий начиональный университет 14-15 мая 2015 года. А. А. Кораблев: Лет сто тому назад, живя в глухом селе, вдали от больших городов и посреди гражданской войны, Михаил Булгаков вспоминал историю об одном английском офичере, который, оказавиись на необитаемом острове, каждое утро начинал с того, что брился. Наверное, это оченъ важно: не изменять своим привычкам. Что быни случилось, делать свое дело. Быть сильнее обстоятельств. В сушности, этим приходится заниматься и нам, господа офичеры... (РАЗДЕЛ 3. ДИСКУССИИ (рецензируемый сборник)».
Военная реальность становится жизненным пространством, в котором люди не просто пережидают, когда закончатся военные действия. Это их реальное «здесь» и «сейчас», в котором надо жить. В таких условиях в Донецке занимаются наукой и проводят конференции.

Литературоведческий сборник продолжает и развивает традиции Донецкой филологической школы. В общей текстовой канве прослеживаются такие тенденции, как опора многих работ на эстетику Бахтина и формулировки ученых Донецкой филологической школы, объединяющей нитью является узкое «сотрудничество» и объединение подходов литературоведения и лингвистики. Отдельно следует отметить документалистский подход, трепетное отношение к каждому высказанному слову, к каждой высказанной мысли - дискуссии зафиксированы в последнем разделе сборника. Такой подход весьма продуктивен, т.к. многие моменты, отраженные в статьях, при обсуждениях становятся импульсом для разработки новых ракурсов научных проблем.

\section{PhDr. Inna Kalita, Ph.D.}

Katedra bohemistiky

Pedagogická fakulta, Univerzita Jana Evangelisty Purkyně

České mládeže 8, 40096 Ústí nad Labem, Česká republika

inna.kalita@ujep.cz 